\title{
Storm Surge Awareness and Intended Evacuation in Low-Lying Areas of Tokyo City
}

\section{Kohei Senoo $^{a^{*}}$, Tomoyuki Takabatake ${ }^{a}$, Miguel Estebana, Tomoya Shibayama ${ }^{a}$}

\author{
${ }^{a}$ Waseda University, 3-4-1 Ookubo, Tokyo, Japan
}

Received: October 22, 2019/ Accepted: September 16, 2020

\begin{abstract}
Japan is a country that is normally considered to be well protected against storm surges, with the population aware of the potential consequences of such events. However, the inundation caused by typhoon Jebi in 2018 at Osaka Bay has highlighted that there is a significant risk of flooding in many areas. In the present paper the authors conducted questionnaire surveys with the aim to gauge the level of storm surge awareness and intended evacuation behaviour of the population of low-lying areas of Tokyo City. The results indicate that respondents have a high awareness regarding storm surges, but lower actual knowledge about the risk in their area and the evacuation plan. Respondents who have higher risk awareness about storm surges often had participated in evacuation drills, and those who knew about the inundation map tend to indicate that they would perform long-distance evacuation. It was also found that respondents who are in their 30 have lower awareness than other age groups. Keywords: storm surge; awareness; natural hazards; Japan; intended evacuation behaviour
\end{abstract}

\section{Introduction}

Awareness about the risk associated with storm surges and the existence or not of appropriate coastal defence systems can influence the level of casualties resulting from tropical cyclones, as shown by the events of major storms that have taken place in recent years, including hurricane Katrina in the USA in 2015 (Shibayama, 2015), cyclone Sidr in Bangladesh in 2007 (Tasnim et al, 2015), cyclone Nargis in Myanmar in 2008 (Tasnim et al, 2014), hurricane Sandy in the USA in 2012 (Mikami et al., 2015) or typhoon Haiyan in the Philippines in 2013 (Mikami et al., 2016, Takagi et al., 2015), amongst others.

\footnotetext{
Corresponding Author

E-mail: esteban.fagan@gmail.com
}

Japan is a country that is frequently affected by tropical cyclones, some of which cause widespread damage. Much of this damage is due to wind, though storm surges have historically also been a major problem. One of the most important events from the point of view of disaster risk management was the 1959 Isewan Typhoon (Vera), which generated a $3.5 \mathrm{~m}$ storm surge in Ise Bay in Japan (Kawai et al., 2006). The storm breached the dikes in the area and flooded the low-lying lands behind them, causing widespread destruction. In the aftermath of this event, the Japanese Government determined that defences around the country would be designed to withstand such a typhoon (i.e. it was designated as the "standard strong typhoon" against which defences should be built). As a result, extensive coastal defences have since been built around the country, which are designed against one of the two following criteria (Kawai et al., 2006):

-The sum of the mean spring high tide level and the maximum storm surge recorded at a tide station or simulated assuming this "standard typhoon"

-The highest tidal level recorded at a tide station.

The first criteria was adopted for densely and seriously important bay areas such as Tokyo, Ise and Osaka Bays, while the second criteria is used for the central region of the Seto Inland Sea (Kawai et al., 2006). As a result of such countermeasures, the cities around Tokyo Bay have not suffered any major damage since the typhoon in the $6^{\text {th }}$ year of the Taisho period (in 1917). This typhoon caused widespread damage, flooding over $200 \mathrm{~km} 2$ and leaving over 1300 people dead or missing. The lowest pressure recorded during the passage of the typhoon was $952.7 \mathrm{hPa}$, and the maximum storm surge measured was +2.1 $\mathrm{m}$ (corresponding to a T.P. (Tokyo Pail ) level of +3.0 m (Miyazaki (1970)).

Despite the presence of such coastal defences throughout the coastline of the country, typhoon Jebi in 2018 went on to flood extensive areas of Kobe and Osaka cities (Takabatake et al., 2018). This weather system struck Japan as a Category 3 typhoon on the Saffir-Simpson scale, and generated a storm surge in excess of T.P. $+3.29 \mathrm{~m}$ and T.P. $+2.33 \mathrm{~m}$ at Osaka and Kobe's tidal stations, respectively. While most of the defences held, several areas located outside of coastal barriers and artificial islands such as Ashiya City (east of Kobe City) were flooded (Takabatake et al., 2018). Many local residents did not evacuate during the typhoon, weathering the storm in their houses (Takabatake et al., 2018). Japanese people can typically be considered to be highly aware about the dangers of natural hazards in general, and typhoons and storm surges in particular, given the large amount of investments and efforts that are being placed into education and training (Kuwasawa et al., 2010, Kodama et al., 2013, Tanimoto and Sano, 2018). However, their awareness about the potential consequences of high intensity typhoons might not be as high as the authorities 
would expect, highlighting the need to clarify the intended evacuation behaviour (if any) of residents.

Awareness about storm surges throughout the world might not be as high as many disaster risk managers believe. For the case of typhoon Haiyan in the Philippines in 2013, residents did not to correctly understand the phenomenon, with many stating that it would have been better for authorities to describe it as a "tsunami" (Esteban et al., 2015, Leelawat et al., 2014). The awareness that inhabitants have about a storm surge appears to be location specific, depending on a number of factors such as education, culture, and the policies of local and national governments (Esteban et al., 2013). This level of awareness is likely to decrease with time after a given event (Esteban et al., 2015), unless appropriate education and societal awareness strategies are put in place (Esteban et al, 2015, Suppasri et al, 2015), though even without it some degree of awareness can manage to be transmitted in the form of stories told from one generation to the next (Gaillard et al., 2008, Viglione et al., 2014).

It is not only necessary for people to have a high awareness about potential natural hazards, but to also know how to evacuate in case these events breach coastline defences. A number of different studies have been conducted regarding evacuation intent. In the United states, several studies have set out to investigate the intended or hypothetical evacuation behaviour from hurricanes (Whitehead et al., 20oo, Huang et al., 2016), wildfires (Mozumder et al., 2008, McLennan et al., 2019) or tsunamis (Fraser et al., 2013, 2016, San Carlos-Arce et al., 2017, Lindell et al., 2015, Wei et al., 2017). Other studies have attempted to clarify the willingness to evacuate of specific groups such as older adults (Gray-Graves et al., 2010) or tourists (Fraser et al., 2013, San Carlos-Arce et al., 2017, Matsumaru and Kawaguchi, 2015). Other surveys on knowledge, attitude and practice have been carried out in Vietnam (Esteban et al., 2014), Trinidad and Tobago (Kanhai et al., 2016, Esteban et al., 2015) or in Japan after disasters had already taken place (Yun and Hamada, 2015). The influence of awareness of local residents' and tourists' evacuation behaviour can be checked using computer simulations, which can help model the lethality of given events (Takabatake et al., 2017) and improve existing countermeasures (Okumura et al., 2017, Takabatake et al. 2018).

Considering the risk of their defence system being breached by an intense storm surge, five wards in Tokyo City (namely Adachi, Edogawa, Katsushika, Koto and Sumida wards) started to prepare long-distance evacuation plans for the eventuality that a strong typhoon with heavy rain affects the city. If their defence system is breached by a strong typhoon, extensive areas could be flooded for over two weeks (due to their ground elevation being lower than sea level, and the need to then pump out the flooded water). Thus, if people do not perform a long-distance evacuation (i.e., evacuate to areas outside the inundation zone) before a typhoon makes landfall, they could be forced to survive in their house surrounded by the sea water (without any electricity, fresh water supply or functioning sewage systems). Research was carried out to verify the capacity of evacuation areas (Makinodan et al. 2013) and the possibility of conducting long-distance evacuation using public train (Kato and Miyagawa, 2011). However, although research continues on the feasibility of long-distance evacuation plans (Katada et al. 2018), at present little attention has been paid to the degree of disaster awareness about storm surges and knowledge about the concept of long-distance evacuation. Thus, there is a fear that very few citizens could actually perform a long-distance evacuation, and might prefer to stay in their residences instead (as their houses might be well-designed concrete structured and the inundation water depth would be relatively limited). The authors conducted a questionnaire survey of residents of Koto and Edogawa wards, the two districts of Tokyo whose elevation is currently below mean water level (Endo et al. 2001) as a consequence of groundwater extraction during the 2oth century, with the aim to obtain a picture of the level of awareness and intended evacuation behaviour in the case of a storm surge. Finally, based on the results of the research the authors make suggestions that could improve disaster risk management in the area.

\section{Methodology}

\subsection{Study Area}

The "Greater Tokyo" area, with 37 million people, constitutes the most populated megalopolis in the world (Japan Statistics Bureau, 2015). Within this vast metropolitan area, the administrative boundaries of Tokyo City itself encompass 13.5 million inhabitants (Japan Statistics Bureau, 2015), with other major cities such as Yokohama and Kawasaki making up the rest. Tokyo alone has a Gross Domestic Product (GDP) higher than any other city in the world, exceeding even London and New York City, with a gross output of 1,479 billion US dollars (PricewaterhouseCoopers, 2009). In terms of geography, Tokyo can be broadly divided into three parts, a hilly side to the west, a low-relief plateau in the centre, and alluvial deposits in the eastern lowlands, which are known as the Koto delta. During the Edo period (which ended in 1868) the lowlands had an extensive network of canals, though following the Meiji restoration significant alterations were made to the waterways around the low-lying parts of Tokyo in the 2oth century, resulting in its present-day topography. Following this period, Tokyo was affected by significant land subsidence due to development during the post-war economic revival. Particularly, land subsidence accelerated during the 1950s and 1960s (Nakajima et al., 2012) due to groundwater extraction, for either industrial purposes or the extraction of natural gas (Tokyo Metropolitan Government, 2010). The Japanese Government enacted and enforced a a number of regulations, and by 1973 subsidence was under control.

Nevertheless, as a result of that historic subsidence many areas of Koto and Edogawa wards (see Fig. 1) are 
currently several metres below mean sea level and would be flooded if the riverbanks and seawalls around their perimeter were overcome by a storm surge (see Fig. 2 and Hoshino et al. 2016). These two wards are characterized by the rivers that run through them, the Sumida, Arakawa and Edogawa rivers. They are mostly residential areas for people working in central Tokyo, with a population of 513,197 (Koto ward website, 2018) and 694,896 (Edogawa ward website, 2018). The wards are well connected and integrated to the rest of the city and are served by several train lines.

Throughout the wards, a multitude of storm surge and tsunami flooding countermeasures can be found (examples are shown in Fig. 2). These include levees surrounding the entire perimeter of each area, storm surge gates protecting the entrance of rivers and canals, elevated entrances of subway stations and flood gates, and a sewage system and pump facilities that are able to discharge excess rainwater. These countermeasures show that disaster preparedness is taken seriously by the authorities, though these defences could be overcome by a strong storm surge.

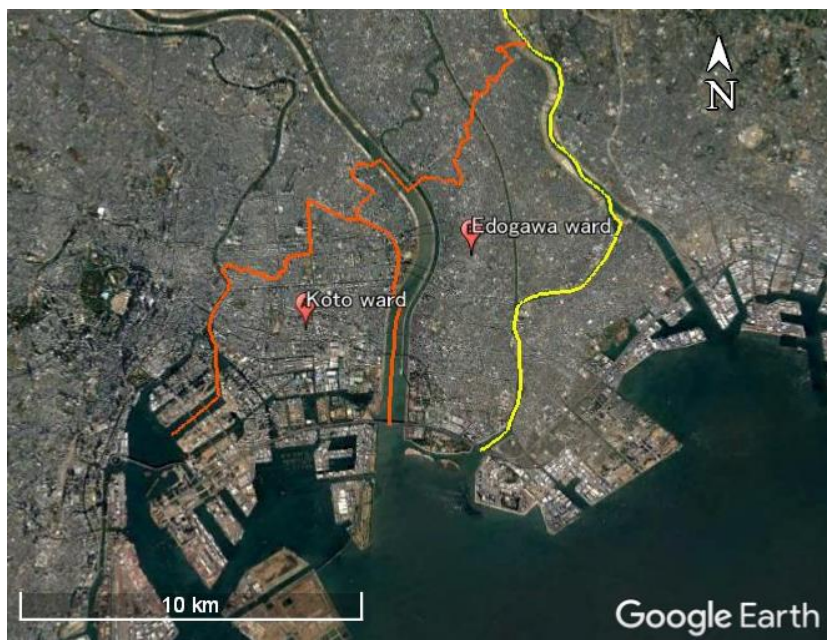

Figure 1 Map of Edogawa and Koto wards, within Tokyo city
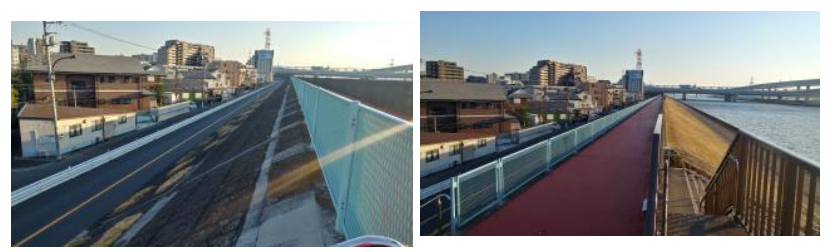

Figure 2 Left: Riverside of Edogawa ward. Right: view from the top of the dyke shown on the left side. The entire area would be flooded if the riverbanks were to fail

\subsection{Sample}

Surveys were conducted using two different methodologies, with the results for each presented separately. First, a survey was administered to a convenience sample of residents on the 14th, 16th, 19th, 25th of August and 15th of September 2018 (mostly corresponding to Japanese summer holidays, which was considered a good opportunity to obtain responses from a wide variety of the public). To do this, members of the public found in the streets or shopping centres were approach while they were walking around, and asked if they would be happy to respond to a survey. All results were recorded on paper and all answers were kept anonymous.

The authors were particularly interested in the awareness of younger respondents who would have been unlikely to have experience any flooding events during their lifetimes. To collect as many replies from younger people as possible, the authors also conducted in parallel an online survey, using the same set of questions. For the online questionnaire a snowball sampling methodology was used, with the lead author first distributing the questionnaire to acquaintances who live in the target area, in order to attempt to increase the number of younger respondents. The survey was made using the Google Forms (Mountain View, CA).

Although the first version of long-distance evacuation plan was issued in 2016, the second version was coincidentally issued on the 22nd of August 2018. As it was widely broadcasted by mass media, respondents who were asked after this day would have been more likely to know about it. However, the authors did not disaggregate the results as the main purpose of the study was to gauge the general level of awareness and intended evacuation behaviour of local residents (not to evaluate the change in it). The survey was originally drafted in English, with the translated version into Japanese being administered to respondents, who took about 10 minutes per individual to complete. The survey was conducted during daytime of both working days and holidays (including the Japanese "Obon" summer break (around the third week of August), as it is easy during this time to find members of the community who might not otherwise be easily accessible during working hours of other days).

The questions asked pertained to whether they were Japanese or not (and further clarification about their birthplace or country of origin, and number of years living in Japan), whether they thought they lived in an area which was at danger of flooding from the sea or a river (on a $5^{-}$ point Likert scale, from 1 ("no danger at all") to 5 ("very strong danger)), if they had experienced a flooding disaster in the past (either from a tsunami, storm surge or river flood), whether they had joined evacuation drills in the last five years, if they knew what a storm surge was and whether they thought it was a danger for them (5-point Likert scale), whether they will evacuate if a strong typhoon approaches (and which mode of transportation they would use), how would they evaluate the risk of a storm surge in the area (5point Likert), if they knew the long-distance evacuation plan for the area and the expected inundation map published by Tokyo City, whether they would follow an evacuation order one or three days before a typhoon (and if they would not do so, then when exactly they would start evacuating, or why they would not evacuate at all), and from where they obtained information about storm surges. Finally, demographic information was also collected (age, 
occupation, gender, place, where they lived and worked (and whether that was in the questionnaire's target area), and who they lived with).

\section{Results}

In total 90 valid responses for the administered questionnaires were collected $(\mathrm{n}=90)$, from 99 completed questionnaires (most of the responses that were excluded were from people living in Sumida ward, which was outside of the target area of the study). For the case of the online questionaires, 54 valid samples were collected $(n=54)$, from 58 completed questionnaires (most invalid samples related to people failing to answer questions regarding their age or place of birth).

\subsection{Demographics}

Table 1 shows a summary of the demographic information for both the administered and online surveys. Generally speaking, few foreigners live in this area (only around $5 \%$ of residents are foreigners, according to Tokyo Metropolitan Government [2020]), and only one respondent was a not a native Japanese (see Table 1). In addition, local people, defined as people who were born in either Koto or Edogawa ward, dominated. Office workers constituted about $50 \%$ of the administered survey, see Table 2. The category of "others" contained a wide variety of answers, including nurses, civil servants, lawyers, independent business owners and executive officers. $68 \%$ of respondents living or working in "Koto ward" (with the number for the online survey being lower, at 57\%), and almost all lived with their family, not unusual given that this is a residential part of Tokyo and that the south part of Koto ward has many high-rise apartments build specifically for families (as opposed to other apartments blocks in Tokyo that might have smaller apartments for single people). $30 \%$ of all respondents have somebody under the age of 18 living with them (particularly high for people in their $30 \mathrm{~s}$ and $40 \mathrm{~s}$ ), though the majority of respondents did not have elderly living with them $(81 \%$ and $93 \%$ those in the administered and online questionnaires, respectively). The greatest majority of people lived in the area, though there were also a number of people working in the wards. $99 \%$ of respondents (for both the administered and online questionnaires, $n=144$ ) indicated that they were Japanese, with most of them originating from Tokyo (53\% of respondents), with the second largest group being from the Kanto region (which encompasses a number of prefectures in the area surrounding Tokyo.
Table 1 Summary of demographic characteristics of respondents. According to census data Koto ward has a population of 518,479 individuals as of 2018 ( $49.4 \%$ of males to $50.6 \%$ females). Edogawa

has a population of 700,296 individuals $(50.4 \%$ males to $49.6 \%$

\begin{tabular}{|c|c|c|c|}
\hline Variable & $\begin{array}{l}\text { Administered } \\
(\mathrm{n}=90)\end{array}$ & $\begin{array}{l}\text { Online } \\
(\mathrm{n}=54)\end{array}$ & $\begin{array}{l}\text { Census of } \\
\text { study } \\
\text { area }\end{array}$ \\
\hline \multicolumn{4}{|l|}{ Gender } \\
\hline Female & $61 \%$ & $54 \%$ & $49.8 \%$ \\
\hline Male & $39 \%$ & $46 \%$ & $50.2 \%$ \\
\hline Unclear/No answer & o\% & $\mathrm{o} \%$ & \\
\hline \multicolumn{4}{|l|}{ Origin } \\
\hline Local & $46 \%$ & $65 \%$ & $95 \cdot 3 \%$ \\
\hline Non-local native & $53 \%$ & $7 \%$ & \\
\hline Foreigners & $1 \%$ & o\% & $4.7 \%$ \\
\hline Unclear/No answer & $\mathrm{o} \%$ & $28 \%$ & \\
\hline \multicolumn{4}{|l|}{ Age } \\
\hline$<29$ & $22.2 \%$ & $55.6 \%$ & $28.3 \%$ \\
\hline $30-39$ & $16.7 \%$ & $1.9 \%$ & $14.1 \%$ \\
\hline $40-49$ & $23.3 \%$ & o\% & $17.8 \%$ \\
\hline $50-59$ & $17.8 \%$ & $1.9 \%$ & $12.8 \%$ \\
\hline $60+$ & $20.0 \%$ & & $27.0 \%$ \\
\hline Unclear/No answer & $\mathrm{o} \%$ & $40.7 \%$ & \\
\hline
\end{tabular}

Table 2 Summary of other characteristics of respondents

\begin{tabular}{|c|c|c|}
\hline Variable & $\begin{array}{l}\text { Administered } \\
(\mathrm{n}=90)\end{array}$ & $\begin{array}{l}\text { Online } \\
(\mathrm{n}=54)\end{array}$ \\
\hline \multicolumn{3}{|l|}{ Occupation } \\
\hline Office worker & $48 \%$ & $24 \%$ \\
\hline Student & $15 \%$ & $58 \%$ \\
\hline Housewife & $28 \%$ & $9 \%$ \\
\hline Others & $9 \%$ & $9 \%$ \\
\hline \multicolumn{3}{|l|}{ Geographical classification } \\
\hline Koto ward & $68 \%$ & $57 \%$ \\
\hline Edogawa ward & $17 \%$ & $41 \%$ \\
\hline No answer/Others & $15 \%$ & $2 \%$ \\
\hline \multicolumn{3}{|l|}{ Living arrangements } \\
\hline With family & $88 \%$ & $94 \%$ \\
\hline Alone & $9 \%$ & $6 \%$ \\
\hline With friends & $1 \%$ & $\mathrm{o} \%$ \\
\hline Others & $2 \%$ & $\mathrm{o} \%$ \\
\hline \multicolumn{3}{|l|}{ Presence of children $<18$} \\
\hline Yes & $34 \%$ & $24 \%$ \\
\hline No & $65 \%$ & $76 \%$ \\
\hline No answer & $1 \%$ & $\mathrm{o} \%$ \\
\hline \multicolumn{3}{|l|}{ Presence of elderly } \\
\hline Yes & $18 \%$ & $7 \%$ \\
\hline No & $81 \%$ & $93 \%$ \\
\hline No answer & $1 \%$ & $\mathrm{o} \%$ \\
\hline \multicolumn{3}{|c|}{ Relationship with target area } \\
\hline Living there & $73 \%$ & $91 \%$ \\
\hline Working \& living there & $10 \%$ & $2 \%$ \\
\hline Working there & $16 \%$ & $7 \%$ \\
\hline Unclear & $1 \%$ & $\mathrm{o} \%$ \\
\hline
\end{tabular}

\subsection{Awareness}

Respondents who were born in the area had a higher risk awareness compared with non-local respondents, as they may have experienced past disasters or received an education about local disasters at school (see Figs. 3 and 4 ) 


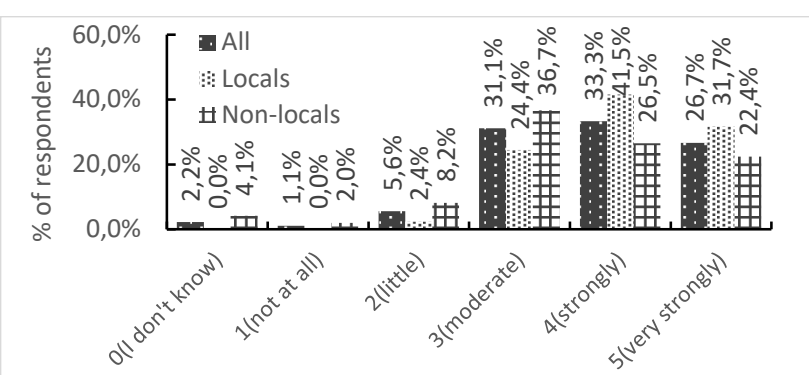

Figure 3 Responses regarding whether the target area was at danger of flooding from the sea or rivers in online survey $(n=90)$

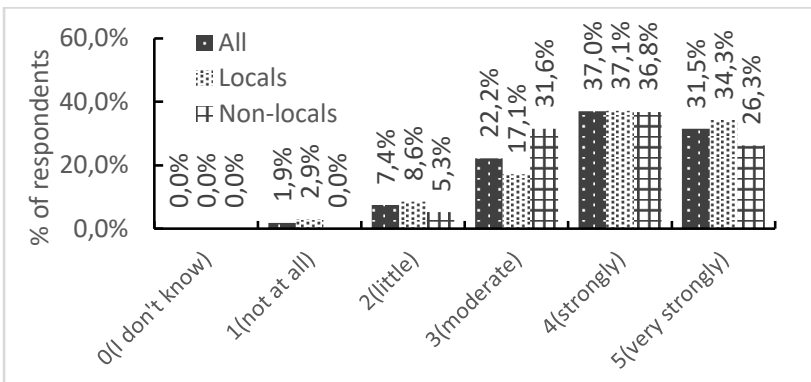

Figure 4 Responses regarding whether the place where they lived was at danger of flooding from the sea or rivers in online survey $(n=54)$

Only a small proportion (14.4\% of respondents in the administered survey and $3.7 \%$ of respondents in the online survey) had experienced some sort of flooding in the past (see Table 3), including some who originated from the Tohoku region and suffered the 2011 Tohoku Earthquake Tsunami. Few respondents had direct experiences with water hazards in this or other areas.

Also, respondents were asked whether they knew what a storm surge was, with about half of them knowing about this phenomenon (see Table 3). Then, they were asked to rate the level of threat posed by it in general (on a 5-point Likert scale, see Figs. 5 and 6), and the level of threat in the target area (again, on a 5-point Likert scale, see Fig. 7 and 8). The greatest majority of respondents in all groups, for both the online and administered surveys indicated that there was a moderate or higher risk, which is in line with historical evidence and current disaster management thinking. Given that most respondents are residents, it is not surprising that Figures 5-6 and 7-8 are similar.

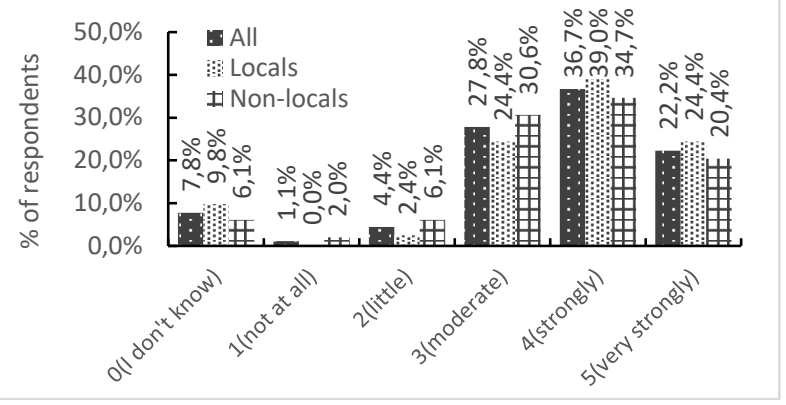

Figure 5 Assessment of the risk posed by storm surges for respondents of the administered survey $(n=90)$

Table 3 Summary of answers of survey

\begin{tabular}{|c|c|c|c|c|}
\hline \multirow[t]{2}{*}{ Variables } & \multicolumn{2}{|c|}{$\begin{array}{l}\text { Administered } \\
(\mathrm{n}=90)\end{array}$} & \multicolumn{2}{|c|}{ Online $(\mathrm{n}=54)$} \\
\hline & Yes & No & Yes & No \\
\hline \multicolumn{5}{|c|}{$\begin{array}{l}\text { Have you experienced some damage from previous } \\
\text { flooding? }\end{array}$} \\
\hline All & $14.4 \%$ & $85.6 \%$ & $3.7 \%$ & $96.3 \%$ \\
\hline Locals & $7.3 \%$ & $93.7 \%$ & $2.9 \%$ & $97.1 \%$ \\
\hline Non-locals & $20.4 \%$ & $79.6 \%$ & $5 \cdot 3 \%$ & $94.7 \%$ \\
\hline
\end{tabular}

Do you know what as storm surge is?

$\begin{array}{lllll}\text { All } & 48.9 \% & 51.1 \% & 48.2 \% & 51.9 \% \\ \text { Locals } & 41.5 \% & 58.5 \% & 51.4 \% & 48.6 \% \\ \text { Non-locals } & 55.1 \% & 44.9 \% & 42.1 \% & 57.9 \%\end{array}$

Have you taken part in evacuation drills in the past years?

$\begin{array}{lllll}\text { All } & 42.2 \% & 57.8 \% & 33.3 \% & 66.7 \% \\ \text { Locals } & 48.8 \% & 51.2 \% & 31.4 \% & 68.6 \% \\ \text { Non-locals } & 36.7 \% & 63.3 \% & 36.8 \% & 63.2 \%\end{array}$

Would you evacuate in the event of a strong typhoon?

$\begin{array}{lllll}\text { All } & 46.7 \% & 53.3 \% & 40.7 \% & 59.3 \% \\ \text { Locals } & 48.8 \% & 51.2 \% & 40.0 \% & 60.0 \% \\ \text { Non-locals } & 44.9 \% & 55.1 \% & 42.1 \% & 57.9 \%\end{array}$

Do you know the evacuation plan for your area?

$\begin{array}{lllll}\text { All } & 31.1 \% & 68.9 \% & 18.5 \% & 81.5 \% \\ \text { Locals } & 29.3 \% & 70.7 \% & 11.4 \% & 88.6 \% \\ \text { Non-locals } & 32.7 \% & 67.4 \% & 31.6 \% & 68.4 \%\end{array}$

Do you know about the extent of the inundation map for your area?

\begin{tabular}{lllll} 
All & $25.6 \%$ & $74.4 \%$ & $24.1 \%$ & $75.9 \%$ \\
Locals & $29.3 \%$ & $70.7 \%$ & $17.1 \%$ & $82.9 \%$ \\
Non-locals & $22.5 \%$ & $77.6 \%$ & $36.8 \%$ & $63.2 \%$ \\
\hline
\end{tabular}




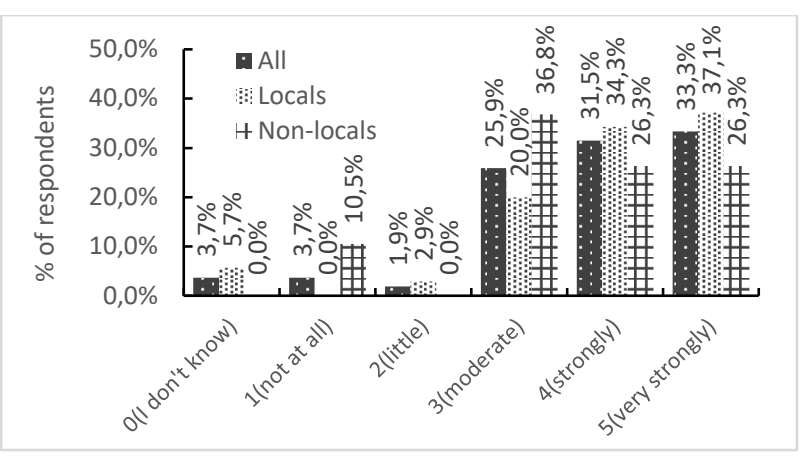

Figure 6 Assessment of the risk that a storm surge posed to respondents of the online survey $(n=54)$

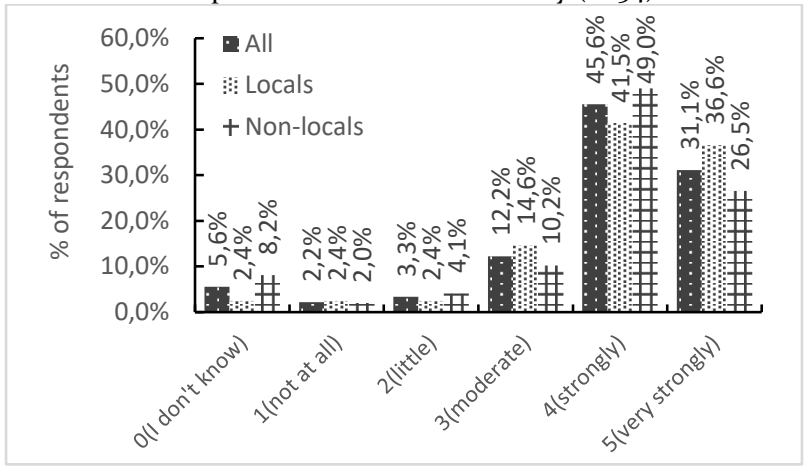

Figure 7 Assessment of storm surge risk that a storm surge posed to the target area for respondents of the administered survey $(n=90)$

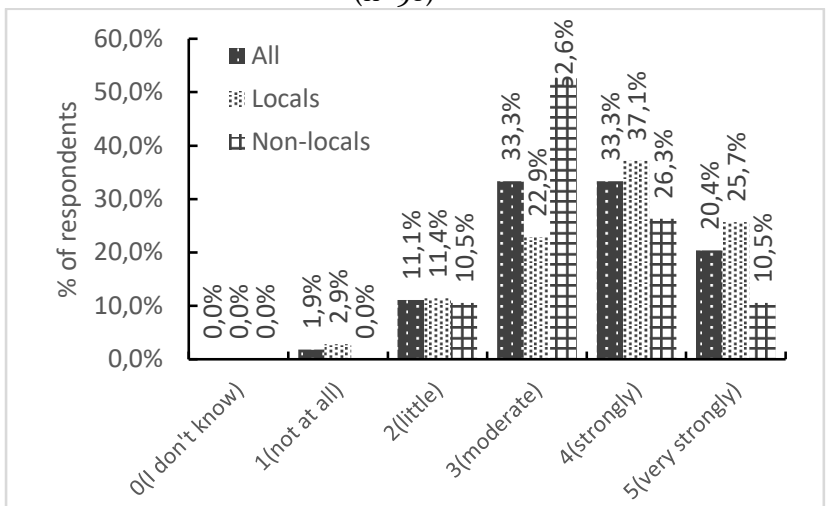

Figure 8 Assessment of storm surge risk a storm surge posed to the target area of the study for respondents of the online survey $(n=54)$

\subsection{Intended evacuation behaviour}

Regarding evacuation drills, $42.2 \%$ of respondents in the administered survey and $33.3 \%$ of respondents in online survey indicating that they had participated in one in the last five years, and little differences observed between locals and non-locals (see Table 3). Almost all respondents participated in the evacuation drill hold at school or at their company. Most respondents did not join in the evacuation drills held by the local government.

Respondents were asked whether they would evacuate if a strong typhoon approached, with $46.7 \%$ and $40.7 \%$ of respondents in the administered and online surveys indicating they would, respectively (Table 3). Regarding the mode of transportation, Figs. 9 and 10 almost all respondents would evacuate on foot (this question was asked only to the respondents who indicated that they would evacuate). This result would thus appear to indicate that many respondents expect to evacuate to the closest evacuation area, rather than outside the ward.

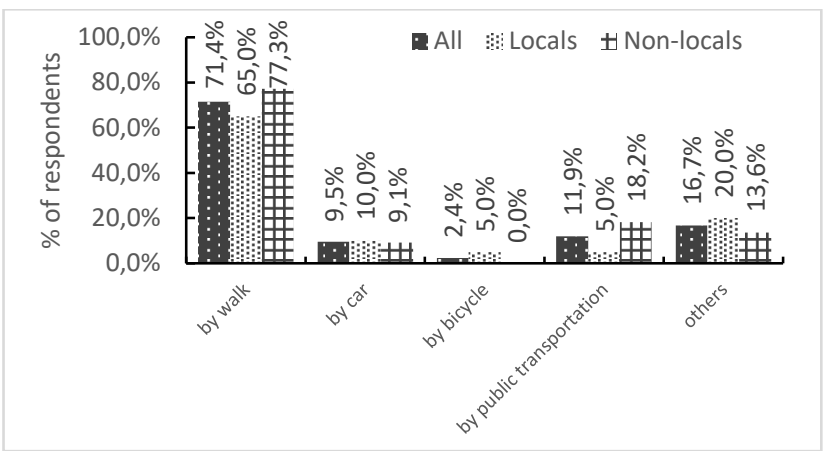

Figure 9 Mode of transportation used for evacuation for respondents of the administered survey $(n=42$, multiple answers allowed)

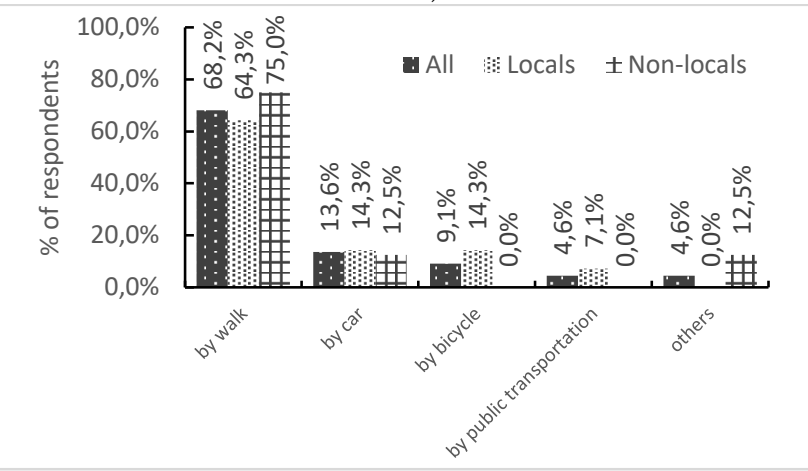

Figure 1o Mode of transportation used for evacuation for respondents of the online survey $(n=22$, multiple answers allowed)

$31.1 \%$ of respondents in the administered survey and $18.5 \%$ of those in the online survey indicated that they knew the evacuation plan for the target area (with $25.6 \%$ and $24.1 \%$, indicating that they knew about the expected extent of inundation, respectively, see Table 3). This indicates a rather low awareness about these evacuation plans, which is worrying as authorities are placing some emphasis on longdistance evacuation (rather than evacuation inside the wards).

As shown in Figs. 11 and 12, $21 \%$ of respondents of the administered survey and $50 \%$ of those in the online survey indicated that they would start to evacuate if they received a voluntary evacuation order two or three days before the event, changing to $44 \%$ and $24 \%$ if this was one day before, respectively. Regardless of whether they would evacuate before the arrival of the typhoon, during or after the typhoons, residents were asked about their intended evacuation direction, with the overall number of respondents who answered "outside of the target area" being similar to that in Figs. 13 and 14. When focusing on 
the answers from those who stated that they would evacuate at some point before the arrival of the typhoon (n $=73$ in the administered survey and $\mathrm{n}=49$ in the online survey), $15.1 \%$ in the administered survey and $24.5 \%$ in the online survey indicated that they would evacuate outside the target area, while $56.7 \%$ and $66.7 \%$ indicated that they would evacuate to nearby evacuation areas, respectively. This suggests that even people who prefer earlier evacuation would not perform a long-distance evacuation.

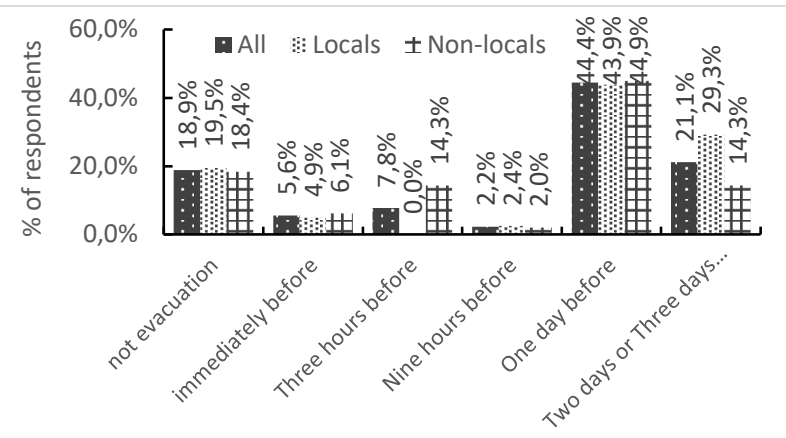

Figure 11 Starting time for evacuation for respondents of the administered survey $(\mathrm{n}=90)$

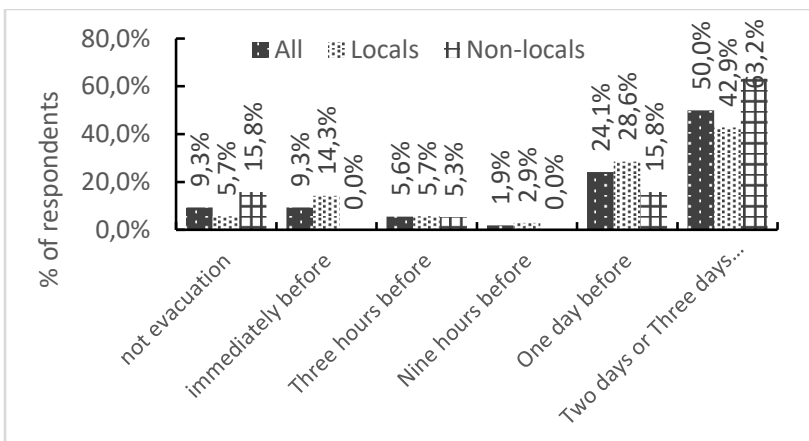

Figure 12 Starting time for evacuation for respondents of the online survey $(n=54)$

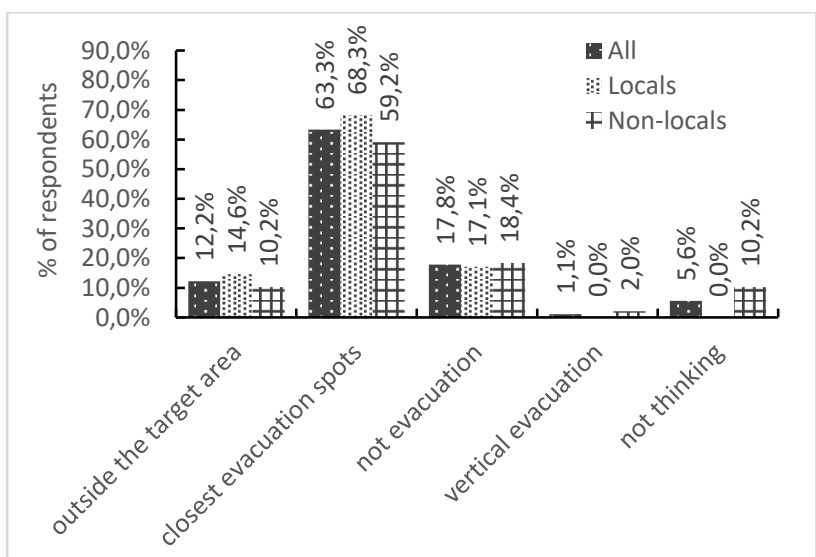

Figure 13 Intended evacuation location for respondents of administered survey $(\mathrm{n}=90)$

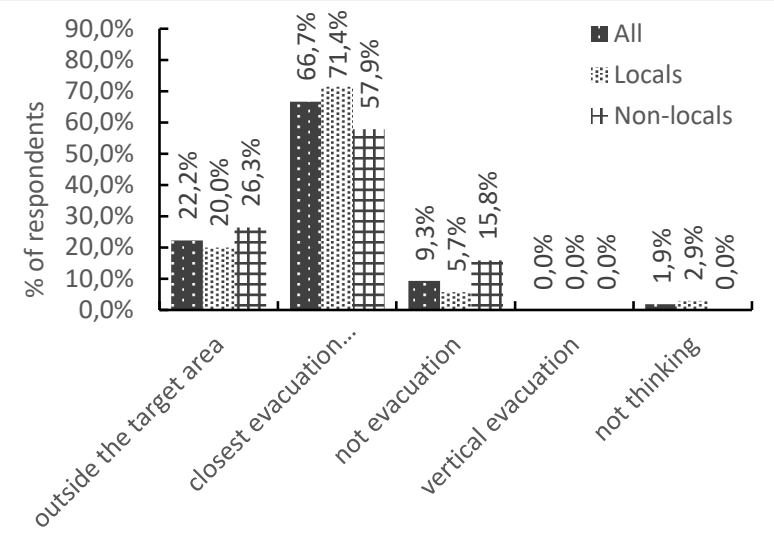

Figure 14 Intended evacuation location for respondents of online survey $(\mathrm{n}=54)$

Finally, respondents were asked about where they obtained information about storm surges and evacuation (see Fig. 15 and 16). Most respondents collected the information from TV, radio and the internet. In the online survey, the number of respondents who answered "internet" was larger than in the administered one, probably because of the younger demographic in this survey sample.

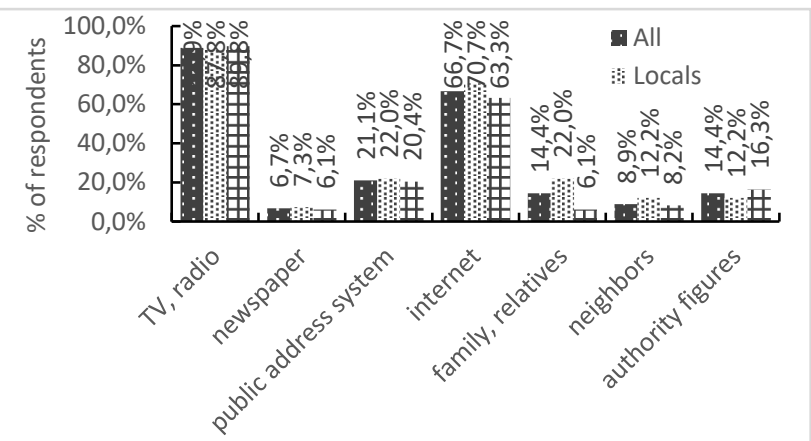

Figure 15 Sources of information regarding storm surges and typhoons for respondents administered survey $(n=90)$

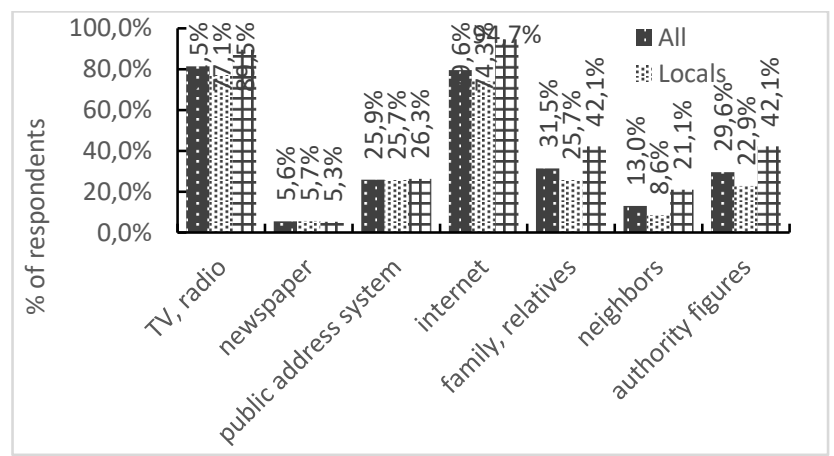

Figure 16 Sources of information regarding of storm surges and typhoons for respondents of online survey $(n=54)$ 


\subsection{Statistical analysis}

The authors used statistical analysis to test two main hypothesis, namely wherthere there is a significant relationship between awareness of the evacuation plan and behaviour (whether they have performed evacuation drills and whether they will evacuate outside the ward when a strong storm approaches), and if there is a significant difference in awareness and preparedness among ages.

The most interesting relationships found by the Chisquared analysis are shown in Table 4 . In this table $\chi^{\wedge} 2$ stands for the value of chi-squared, whereas $\alpha$ denotes the level of significance. It should be noted that a chi-squared analysis only finds whether there is a relationship between two questions, and not what this relationship is. Thus, the authors conducted a more detailed analysis in Tables 5 and 6 , which show how respondents who know the evacuation plan also tend to have participated in the evacuation drill. In addition, the respondent who knew about the inundation map tend to evacuate to areas outside the study site (longdisatance evacuation). This highlights the importance of disseminating information about this map in order to ensure that residents perform long-distance evacuation.

Table 4 Significant results from Chi-squared analysis

\begin{tabular}{|c|c|c|c|c|}
\hline \multirow[t]{2}{*}{ Variables } & \multicolumn{2}{|c|}{$\begin{array}{l}\text { Respondents who } \\
\text { knew the } \\
\text { evacuation plan } \\
\text { for the target } \\
\text { area }\end{array}$} & \multicolumn{2}{|c|}{$\begin{array}{l}\text { Respondents who } \\
\text { knew about the } \\
\text { expected extent of } \\
\text { inundation map }\end{array}$} \\
\hline & $\chi^{2}$ & $\alpha$ & $\chi^{2}$ & $\alpha$ \\
\hline $\begin{array}{l}\text { Participated in an } \\
\text { evacuation drill within } \\
\text { last } 5 \text { years }\end{array}$ & 6.750 & $\underset{*}{0.93 \% *}$ & & \\
\hline $\begin{array}{l}\text { Will relocate to outside } \\
\text { the study area if a } \\
\text { strong typhoon } \\
\text { threatens Tokyo }\end{array}$ & & & 9.539 & $4.89 \%$ * \\
\hline
\end{tabular}

*Significant at .05 level. **Significant at .o1 level.

Table 5 Cross-tabulation of Chi-squared analysis regarding evacuation drills

\begin{tabular}{cccc}
\hline \multirow{2}{*}{ Variables } & & \multicolumn{2}{c}{$\begin{array}{c}\text { Whether the respondents } \\
\text { participated in the evacuation drill } \\
\text { within 5 years or not }\end{array}$} \\
\cline { 2 - 4 } & Yes & No \\
\hline $\begin{array}{c}\text { Respondents knew } \\
\text { evacuation plan for } \\
\text { the target area? }\end{array}$ & Yes & $39.3 \%$ & $60.7 \%$ \\
\hline
\end{tabular}

Table 6 Cross-tabulation of Chi-squared analysis regarding evacuation direction intention

\begin{tabular}{|c|c|c|c|c|c|c|}
\hline & & \multicolumn{5}{|c|}{$\begin{array}{l}\text { Where the respondents evacuate if strong } \\
\text { typhoon will come }\end{array}$} \\
\hline \multicolumn{2}{|c|}{ Variables } & $\begin{array}{l}\text { Outsi } \\
\text { de the } \\
\text { target } \\
\text { area }\end{array}$ & $\begin{array}{l}\text { Closest } \\
\text { evacuati } \\
\text { on spots }\end{array}$ & $\begin{array}{l}\text { Not } \\
\text { evacua } \\
\text { te }\end{array}$ & $\begin{array}{l}\text { Vertical } \\
\text { evacuati } \\
\text { on }\end{array}$ & $\begin{array}{l}\text { Not } \\
\text { thinking }\end{array}$ \\
\hline \multirow{2}{*}{$\begin{array}{l}\text { Responde } \\
\text { nts knew } \\
\text { evacuation } \\
\text { plan for } \\
\text { the target } \\
\text { area? }\end{array}$} & Yes & $\begin{array}{c}27.8 \\
\%\end{array}$ & $47.2 \%$ & $16.7 \%$ & o.o\% & $8.3 \%$ \\
\hline & No & $13.0 \%$ & $70.4 \%$ & $13.9 \%$ & $0.9 \%$ & $1.8 \%$ \\
\hline
\end{tabular}

In addition, the authors analysed the relationship between age and awareness about disasters using descriptive statistics, as shown in Figure 17 and Table 8. In Table 7, "low" means that the respondents answered "Little", "not at all" or "I don't know", in the 5-points Likert scale. Respondents who are in their 30 clearly have a lower awareness about disasters, as explained later in the discussion. It was also found from Fig. 17 that the older respondents are, the less inclined they appear to evacuate.

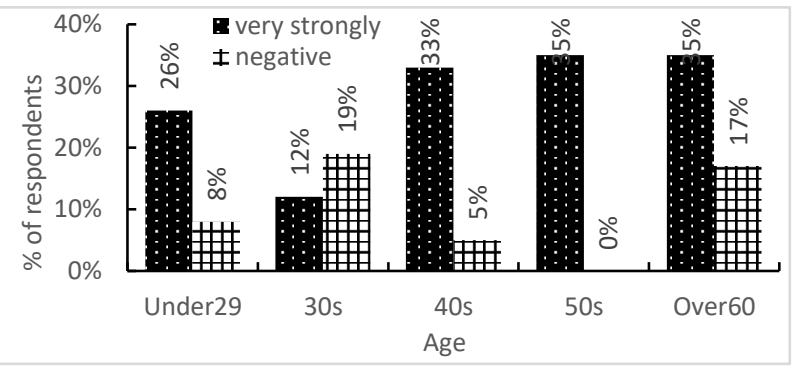

Figure 17 Relationship between awareness of flooding danger in the target area and age

Table 7 Relationship between age and awareness

Variables
$\begin{aligned} & \text { Under } \\ & 29\end{aligned}$




\section{Discussion}

\subsection{Survey characteristics and limitations}

The locations where the survey took place were shopping centres and parks, which were chosen as people in such areas in Japan are more likely to stop and answer a survey. The fact that office workers constituted most of respondents is not unusual in Tokyo and could also be due to the questionnaires being conducted during the Japanese obon summer break (at other times of the year it would be difficult to capture the thoughts of so many of them during working hours). Nevertheless, this could have also lead to a skewed sample, as people could have been away visiting relatives or on holidays.

The majority of respondents of the online survey were "students", as the starting point of the snowball sampling were acquaintances of the lead author.

\subsection{Opinions from local government}

Key informants from local government (in total four were contacted, two from Edogawa ward and one from Koto ward, plus one other residential community leader) explained that they publicised their evacuation plans using the internet, TV, and then public magazine and mailing system, and that hey cooperate with residential community associations and continue to perform evacuation and earthquake disaster drills. According to them, this may have resulted in people confusing the evacuation plan against earthquake with that for a storm surge.

According to the surveys, respondents in their zos have low disaster awareness, with key informan interviewees noting that people in their late 20 s to 30 often start new families and have children. This results in them being very busy, and they find it difficult to collect information about evacuation plans, or take part in drills. It is also worth noting that the education curriculum of elementary students in Japan was changed in 1998 to include a new type of course that has contents tailored to each region, and which often describes past disasters and other such relevant information. However, only those who are under 29 would have had the chance to take this course while at school.

Regarding disaster experience, people in their people $40 \mathrm{OS}$ experienced small-scale floods in Koto ward during their childhood, raising awareness. However, this awareness has faded as the generations passed, as the younger members of the community only learnt about the disaster at school (et al., 2013). However, those in the zos are in between, and thus have neither experienced the event or received recent education about potential disasters.

The second point is that the older respondents are, the less inclined they appear to evacuate. The key informant interviewees indicated that the reason for this resides in the history of both Koto and Edogawa wards as residential quarters of Tokyo (with the exception of the south part of Koto ward, which is reclaimed land). Older respondents feel that, in Japanese culture and as heads of their family, they should protect their land and house, which makes it unlikely that they will decide to evacuate in the case of a storm surge (making it also unlikely that other family members will evacuate). Those over 40 have experienced a past water disaster in Koto ward, though they might overestimate the performance of modern infrastructure and that the new river dykes and other infrastructure can protect them. However, given the experiences of the 2011 tsunami or typhoon Jebi in 2018, infrastructure should not be relied on to protect the life of people. Citizens should always evacuate when faced with a strong typhoon that is stronger than any experienced in modern times (Takabatake et al., 2018).

The key informant interview highlighted how in the case of Edogawa ward evacuation centres will not be opened officially in the case of a strong typhoon. Instead, they expect all evacuees to head outside of the Edogawa ward. If evacuees choose to perform vertical evacuation, they should be aware that the local government will not be able to support them if the area is flooded, and that they might need to stock provisions while they are awaiting rescue. On the other hand, in the case of Koto ward, if a strong typhoon approaches they expect citizens to evacuate to the South part of Koto ward (which are reclaimed area that are higher than elsewhere in the ward) or perform long-distance evacuation. Where the citizens should evacuate to would depend on the typhoon and Koto ward's condition. In this sense, their preparations are a bit vague, compared to the obligatory nature of the messages from Edogawa ward.

Finally, one of the community leaders interviewed highlighted that his community had made suggestions to the local ward government about evacuation planning (these are suggestions, as the ward office is ultimately responsible for evacuation), but they indicate a high level of awareness and proactive planning for disaster.

\subsection{Significant of sea level rise and climate change}

There is a risk that a strong storm could overcome present day defences and flood Koto and Edogawa wards, in the same way that typhoon Jebi flooded some cities in Osaka Bay in 2018. These existing risks will be exacerbated by future sea level rise and climate change. Global warming could lead to an increase in the intensity of future typhoons, as highlighted by the $5^{\text {th }}$ Assessment Report of the Intergovernmental Panel on Climate Change (IPCC AR5, Church et al., 2013), which could lead to higher storm surges than what could be expected at present (Nakamura et al., 2016). Rising sea levels will further compound this problem, as satellite observations show that since 1993 sea levels have been rising at a rate of around $3 \mathrm{~mm}$ per year (IPCC AR4). According to the IPCC $\mathrm{AR}_{5}$, sea levels are likely to rise by between 26 and $82 \mathrm{~cm}$ by 2100 , though recent work on probabilistic process-based models that take into account rapid losses in the Antarctic ice sheets indicates that it 
could be as high as 2.97-3.39m (see Kopp et al., 2017, Le Bars et al., 2017).

The combination of both an increase in typhoon intensity and sea level risk would greatly increase the level of the threat posed to Tokyo Bay (Hoshino et al., 2016), highlighting the relevance of the present work. Essentially, Tokyo City will have to progressively build higher defences to maintain risk at the present level, though given uncertainties in how typhoon strengths will change in the future, it will also be necessary to improve evacuation policies in the city.

\subsection{Measures to improve resilience and contribute to the long-term sustainability and human security}

Following the results outlined above the authors have made a series of recommendations for the local government, private companies and the residential community, with the aim of improving long-term resilience and enhancing human security to natural disasters. In the field of sustainability, resilience has a number of definitions (Asokan et al., 2017), though arguably in the modern world one of the most important considerations is to ensure that there are no human casualties (i.e. to assure that all lives can be saved when natural hazards take place).

Firstly, local governments should take steps to implement evacuation drills against storm surges. While it is obviously difficult, making this compulsory at least once a year would increase risk awareness and make residents aware of the long-distance evacuation plan. Secondly, local governments should attempt to address some of the confusion amongst citizens, who confuse procedures for the evacuation for earthquakes and storm surges. For this, local governments can make attempts to publicly disseminate the inundation map for the storm surge. From the Chi-squared analysis it is clear that there is close relationship between knowledge about the inundation map and long-distance evacuation. Given that many in their zos appear to have low levels of awareness, this section of the community should be particularly targeted. Possible ways of doing so would involve dissemination activities and joint evacuation exercises involving parents and children at day care and elementary schools.

Railways companies are one of the cornerstones of longdistance evacuation in Japan. Thus, they should carefully consider their plans for mass transit service suspension during typhoons, and attempt to liaise with local authorities in order to encourage early long-distance evacuation. Finally, the residential community should clearly attempt to engage with nearby communities in other wards, as strong bongs in the case of emergency are can help smoothen the evacuation process.

\section{Conclusion}

The high number of storm surge events reported in the media in recent times has raised awareness about the consequences of these phenomena throughout the world. However, typhoon 2018 typhoon Jebi showed how many residents of coastal areas in Japan are relatively complacent, trusting existing defences and failing to evacuate. While this can be understood given the relative strength of Japanese coastal defences, there is nevertheless the chance than in the future a powerful typhoon could hit Tokyo Bay and overcome coastal defences. Such a strong event would probably be predicted in advanced, and it would be necessary for coastal residents to evacuate (vertically at least, but preferably long-distance) to avoid a massive loss of life, particularly along the Koto and Edogawa wards (given that they are situated below water level).

The results of the present work showed the necessity to overcome current Japanese evacuation mindsets in order to ensure the security of its population, whereas residents always try to evacuate to the closest designated evacuation area. Japan frequently experiences strong earthquakes, and thus many Japanese tend to equate disasters with earthquakes, though in the case of storm surges in low-lying regions in Tokyo City it is necessary to evacuate to areas outside the inundation zone, rather than heading to the closest evacuation area (in which they might need to survive for a certain period of time without outside help). Such confusion in how to evacuate when faced with a water hazards could increase mortality rates, and it is thus necessary for local governments and residential communities to inform citizens on how best to react. For understanding how best to react, it is crucial that evacuation drills against storm surges are regularly implemented.

In addition, through this survey the authors found that those in their 305 appeared to have lowed disaster awareness, and efforts should be made to engage and raise awareness about this section of the community. The dissemination of the inundation map appears to be the best way to improve awareness about the need for long-distance evacuation.

\section{Acknowledgements}

The present work was performed as a part of activities of Research Institute of Sustainable Future Society, Waseda Research Institute for Science and Engineering, Waseda University.

\section{References}

[1] Asokan, V., Yarime, M. and Esteban, M. (2017) "Introducing Flexibility to Complex, Resilient Socio-Ecological Systems: A Comparative Analysis of Economics, Flexible Manufacturing Systems, Evolutionary Biology and Supply Chain Management", Sustainability, 8 (9), 1091. 
[2] Cahyanto, I., Pennington-Gray, L., Thapa, B., Srinivasan, S., Villegas, J., Matyas, C., \& Kiousis, S. (2014). An empirical evaluation of the determinants of tourist's hurricane evacuation decision making. Journal of Destination Marketing \& Management, 2(4), 253-265.

[3] Church, J.A., P.U. Clark, A. Cazenave, J.M. Gregory, S. Jevrejeva, A. Levermann, M.A. Merrifield, G.A. Milne, R.S. Nerem, P.D. Nunn, A.J. Payne, W.T. Pfeffer, D. Stammer and A.S. Unnikrishnan, 2013: Sea Level Change. In: Climate Change 2013: The Physical Science Basis. Contribution of Working Group I to the Fifth Assessment Report of the Intergovernmental Panel on Climate Change [Stocker, T.F., D. Qin, G.-K. Plattner, M. Tignor, S.K. Allen, J. Boschung, A. Nauels, Y. Xia, V. Bex and P.M. Midgley (eds.)]. Cambridge University Press, Cambridge, United Kingdom and New York, NY, USA.

[4] Edogawa ward Website, 2018, https://www.city.edogawa.tokyo.jp/eoo4/kuseijoho/gaiyo/tokei /jinko/jinkozo.html Accessed 4 February 2019.(in Japanese)

[5] Endo, T., Kawashima, S. and Kawai, M., (2001) "Historical Review of Development of Land Subsidence and its Cease in Shitamachi Lowland, Tokyo", Journal of Japan Society of Engineering Geology, Vol.42, No.2, pp.74-87. (in Japanese)

[6] Esteban, M., Takagi, H. and Shibayama, T., (2015) Handbook of Coastal Disaster Mitigation for Engineers and Planners, Edited Book, Butterworth-Heinemann (Elsevier), Oxford, UK

[7] Esteban, M. Tsimopoulou, V., Mikami, T., Yun, N. Y., Suppasri, A. and Shibayama,T. (2013) "Recent Tsunami Events and Preparedness: Development of Tsunami Awareness in Indonesia, Chile and Japan”, Journal of Disaster Risk Reduction, pp. 84-97

[8] Esteban. M. Thao, N. D., Takagi, H., Valenzuela, P., Tam, T. T., Trang, D.D.T. and Anh, L. T. (2014) Storm surge and tsunami awareness and preparedness in central Vietnam. In: Thao, N.D., Takagi, H. and Esteban, M. (eds) Coastal Disasters and climate change in Vietnam. Elsevier, Oxford, pp. 321-326

[9] Esteban, M., Valenzuela, V. P., Matsumaru, R., Mikami, T., Shibayama, T., Takagi, H., Nguyen, D. T., De Leon, M. (2015) "Storm Surge Awareness in the Philippines Prior to Typhoon Haiyan: a Comparative Analysis with Tsunami Awareness in Recent Times", Coastal Engineering Journal Vol. 58 No. 1

[10] Esteban, M., Bricker, J., San-Carlos Arce, R., Takagi, H., Namyi, Y., Chaiyapa, W., Sjogren., A. and Shibayama, T. (2018) "Tsunami Awareness, A comparatives assessment between Japan and the USA", Natural Hazards 93 (3), 1507-1528.

[11] Fraser, S. A., Leonard, G., S and Johnston, D., M. (2013) Intended Evacuation Behaviour in a Local Earthquake and Tsunami at Napier, New Zealand, GNS Science Report 2013/26, 55pp.

[12] Fraser, S. A., Doyle, E. E., Wright, K. C., Potter, S. H., McClure, J., Johnston, D. M., Leonard, G.S., Coomer, M.A., Becker, J.S., \& Johal, S. (2016). Tsunami response behaviour during and following two local-source earthquakes in Wellington, New Zealand. International Journal of Disaster Risk Reduction, 16, 123-133.

[13] Gaillard, J. C., Clave, E., Vibert, O., Azhari, Defi, Denain, J. C., Efendi, Y., Grancher, D., Liamzon, C. C., Sari, D. R., and Setiawan, R. (2008) Ethnic groups' resonse to the 26 December 2004 earthquake and tsunami in Aceh, Indonesia. Natural Hazards 47, 17-38.

[14] Gray-Graves, A., Turner, K. W., \& Swan, J. H. (2010). Sustainability of seniors: Disaster risk reduction management. The Journal of Aging in Emerging Economies, 2(2), 64-78
[15] Hoshino, S., Esteban, M., Mikami, T., Takagi, H. and Shibayama, T. (2016) "Estimation of Increase in Storm Surge Damage Due to Climate Change and Sea Level Rise in the Greater Tokyo Area", Natural Hazards, Vol. 80 (1), pp. 539-565.

[16] Huang, S-K., Lindell, M.K. \& Prater, C.S. (2016a). Who leaves and who stays? A review and statistical meta-analysis of hurricane evacuation studies. Environment and Behavior, 48, 991-1029. DOI: 10.1177/o013916515578485.

[17] Japan Statistics Bureau, 2015, Population Census, https://www.e-stat.go.jp/. Accessed 19 January 2018.

[18] PricewaterhouseCoopers, 2009. http://www.pwc.com/ Accessed 15 Sept 2012

[19] Kanhai, L. D. K., Singh, D, Lauckner, B., Ebi, K. L. and Chadee, D. (2016) Knowledge, attitude and practices of coastal communities in Trinidad and Tobago about tsunamis, Natural Hazards. DOI 10.10007/s11069-015-2138-3

[20] Katada, T., Kuwasawa, N., Tada, N. and Yoshimatsu, N. (2018). "Survey of Residents' Intentions about Long-distance Evacuation for Large-scale Flood in Big Cities", Journal of Japan Society for Disaster Information Studies, No.16-1, pp.27-35. (in Japanese)

[21] Kato, T. and Miyagawa, Y. (2011). "Analysis on possibility of long distant evacuation by railways in below-sea-level area in Tokyo", Production Research published by Institute of Industrial Science, The University of Tokyo, Vol.63, No.4 pp.103-107. (in Japanese)

[22] Kawai, H, Hashimoto, N. and Matsuura K., 2006. Improvement of Stochastic Typhoon Model for the Purpose of Simulating Typhoons and Storm Surges under Global Warming, Proceedings of the 3oth International Conference on Coastal Engineering (ICCE2006), Vol.2, pp.1838-1850.

[23] Kodama, M., Katada, T., Kuwasawa, N., Shimizu, A., Wada, M. and Kobayashi, K. (2013). "Study on the education to improve residents' intention to evacuate against the storm surge disaster", Journal of Japan Society of Civil Engineers (Coastal Engineering), Vol.69, No.2 pp. I_1356-I_136o. (in Japanese)

[24] Kopp, R. E., DeConto, R. M., Bader, D. A., Hay, C. C., Horton, R. M., Kulp, S., Oppenheimer, M., Pollard, D. and Strauss, B. H. (2017) Evolving Understanding of Antarctic Ice-Sheet Physics and Ambiguity in Probabilistic Sea-Level Projections. Earth's Future, 5, 1217-1233, https://doi.org/10.1002/2017EFooo663

[25] Koto ward Website, 2018, https://www.city.koto.lg.jp/o60305/kuse/profile/shokai/15817.h tml Accessed 4 February 2019(in Japanese)

[26] Kuwasawa, N., Katada, T., Sakai, M., Asano, K., (2010). "Study on Evacuation Measures and Disaster Education by using of Storm Surge Evacuation Simulator", Journal of Research and lecture of Infrastructure Planning and Management, Vol.41, CD-ROM(326). (in Japanese)

[27] Le Bars, D., Drijfhout, S. and Vries, H. (2017) A high-end sea level rise probabilistic projection including rapid Antarctic ice sheet mass loss. Environmental Research Letters, 12, 044013.

[28] Leelawat, N, Mateo, C. M. R., Gaspay, S. M., Suppasri, A., Imamura, F. (2014) Filipinos "Views on the Disaster Information for the 2013 Super Typhoon Haiyan in the Philippines", International Journal of Sustainable Future for Human Security, J-SustaiN. Vol. 2 No. 2 pp. 61-73.

[29] Lindell, M.K., Prater, C.S., Gregg, C.E., Apatu, E., Huang, S-K. \& $\mathrm{Wu}, \mathrm{H}-\mathrm{C}$. (2015). Households' immediate responses to the 2009 Samoa earthquake and tsunami. International Journal of Disaster Risk Reduction, 12, 328-340. doi: 10.1016/j.ijdrr.2015.03.003 
[30] Makinodan, K., Fujiu, M. and Ohara, M. (2013) "Study on Necessary of Evacuation Centers in Koto Delta Area during Metropolitan Large-scale Flood -Considering both Inland Evacuation and Wide-area Evacuation-" , Journal of Institute of Social Safety Science, No.20, pp.39-48. (in Japanese)

[31] Matsumaru, R. and Kawaguchi. R. (2015), "Awareness on Tsunami Disaster of Visitors - Case of Enoshima, Katase and Kugenuma Area in Kanagawa, Japan", Proceedings for JSCE (Japan Society of Civil Engineers) 2015 Annual Meeting (DVDROM), IV-o44 (p87 - p88), JSCE, September 2015.

[32] Matyas, C., Srinivasan, S., Cahyanto, I., Thapa, B., PenningtonGray, L., \& Villegas, J. (2011). Risk perception and evacuation decisions of Florida tourists under hurricane threats: a stated preference analysis. Natural hazards, 59(2), 871-890.

[33] McLennan, J., Ryan, B., Bearman, C., \& Toh, K. (2019). Should we leave now? Behavioral factors in evacuation under wildfire threat. Fire Technology, 55(2), 487-516.

[34] Mikami, T., Esteban, M. and Shibayama, T. (2015) "Storm Surge in New York City Caused by Hurricane Sandy in 2012" in Handbook of Coastal Disaster Mitigation for Engineers and Planners. Esteban, M., Takagi, H. and Shibayama, T. (eds.). Butterworth-Heinemann (Elsevier), Oxford, UK

[35] Mikami, T., Shibayama, T., Takagi, H., Matsumaru, R., Esteban, M., Nguyen, D. T., De Leon, M., Valenzuela, V. P., Oyama, T., Nakamura, R., Kumagai, K. and Li, S. (2016) "Storm Surge Heights and Damage Caused by the 2013 Typhoon Haiyan along the Leyte Gulf Coast", Coastal Engineering Journal. Vol. 58 No. 1

[36] Miyazaki, M., 1970. Tsunami Storm Surge and coastal Disasters. Ed. By Wadachi, K., Kyouritsu Shuppan (in Japanese)

[37] Mozumder, P., Raheem, N., Talberth, J., \& Berrens, R. P. (2008). Investigating intended evacuation from wildfires in the wildland-urban interface: application of a bivariate probit model. Forest Policy and Economics, 10(6), 415-423

[38] Nakajima, H., Kaneko H. and Tsuchida, M. (2012) The management of land subsidence and groundwater conservation in Tokyo, Journal of Groundwater Hydrology, Vol. 52(1), pp. 3547

[39] Nakamura, R., Shibayama, T., Esteban, M. and Iwamoto, T. (2016) "Future Typhoon and Storm Surges Under Different Global Warming Scenarios: Case Study of Typhoon Haiyan (2013)", Natural Hazards, Vol. 82 (3) pp. 1645-1681.

[40]Okumura, N., Jonkman, S., N., Esteban, M., Hofland, B. and Shibayama, T. (2017) "A method for tsunami risk assessment - a case study for Kamakura, Japan” Natural Hazards, 88 (3) 14511472.

[41] San Carlos-Arce, R., Onuki, M., Esteban, M. and Shibayama, T. (2017) "Risk Awareness and Intended Tsunami Evacuation Behaviour of International Tourists in Kamakura City, Japan”. International Journal of Disaster Risk Reduction 23, 178-192.

[42] Shibayama, T. (2015) "2005 Storm Surge by Hurricane Katrina", in Handbook of Coastal Disaster Mitigation for Engineers and Planners. Esteban, M., Takagi, H. and Shibayama, T. (eds.). Butterworth-Heinemann (Elsevier), Oxford, UK

[43] Suppasri, A., Abe, Y., Yasuda, M., Fukutani, Y. and Imamura, F. (2015) Tsunami Signs, Memorials and Evacuation Drills in Miyagi Prefecture after the 2011 Great East Japan Tsunami, in Handbook of Coastal Disaster Mitigation for Engineers and Planners. Esteban, M., Takagi, H. and Shibayama, T. (eds.). Elsevier

[44]Takagi, H. and Esteban, M. (2015) "Statistics of Tropical Cyclone Landfalls in the Philippines -Unusual Characteristics of 2013 Typhoon Haiyan", Journal of Natural Hazards DOI: 10.1007/s11069-015-1965-6
[45] Takabatake, T., Shibayama, T., Esteban, M., Ishii, H. and Hamano, G. (2017) "Simulated Tsunami Evacuation Behaviour of Local Residents and Visitors in Kamakura, Japan”. International Journal of Disaster Risk Reduction 23, 1-14

[46] Takabatake, T., Shibayama, T., Esteban, M. and Ishii, H. (2018) "Advanced casualty estimation based on tsunami evacuation intended behavior: Case study at Yuigahama Beach, Kamakura, Japan”. Natural Hazards 92 (3) 1763-1788

[47] Takabatake, T., Mall, M., Esteban, M., Nakamura, R., Kyaw, T. O., Ishii, H., Valdez, J. J., Nishida, Y., Noya, F., and Shibayama, T. (2018) "Field Survey of 2018 Typhoon Jebi in Japan: Lessons for Disaster Risk Management", Geosciences (accepted).

[48] Tanimoto, T. and Sano, M. (2018) "VR Disaster Training System for Improving Disaster Awareness", IPSJ Interaction 2018 of Information Processing Society of Japan, pp.353-358 (in Japanese)

[49]Tasnim, K. M., Shibayama, T., Esteban, M., Takagi, H., and Ohira, K. (2014) "Field Observation and Numerical Simulation of Past and Future Storm Surges in the Bay of Bengal: Case Study of Cyclone Nargis", Natural Hazards, Vol 75:pp 1619-1647

[50] Tasnim, K.M. Esteban, T., Shibayama, T. and Takagi, H. (2015) "Observations and Numerical Simulations of Storm Surge due to Cyclone Sidr 2007 in Bangladesh" in Handbook of Coastal Disaster Mitigation for Engineers and Planners. Esteban, M., Takagi, H. and Shibayama, T. (eds.). Butterworth-Heinemann (Elsevier), Oxford, UK

[51] Tokyo Metropolitan Government (2010) Lowland River Projects in Tokyo. River Department, Bureau of Construction, Tokyo Metropolitan http://www/kensetsu.metro.tokyo.jp/

[52] Tokyo Metropolitan Government (2020) Statistics of Tokyo. https://www.toukei.metro.tokyo.lg.jp/index.htm

[53] Viglione, A., Baldassarre, G., Bradimarte, L., Kuil, L., Carr, G., Salina, J. L., Scolobig, A. and Bloschl, G. (2014) Insights from socio-hydrology modelling on dealing with flood risk - Roles of collective memory, risk-taking attitude and trust. Journal of Hydrology, 518, 71-82.

[54] Wei, H-L., Wu, H-C., Lindell, M.K., Huang, S-K., Shiroshita, H., Johnston, D.M. \& Becker, J.S. (2017). Assessment of households' responses to the tsunami threat: A comparative study of Japan and New Zealand. International Journal of Disaster Risk Reduction, 25, 274-282. DOI: 10.1016/j.ijdrr.2017.09.011

[55] Whitehead, J. C., Edwards, B., Van Willigen, M., Maiolo, J. R., Wilson, K., \& Smith, K. T. (200o). Heading for higher ground: factors affecting real and hypothetical hurricane evacuation behavior. Global Environmental Change Part B: Environmental Hazards, 2(4), 133-142.

[56]Yun. N.Y. and Hamada. M. (2015). Evacuation Behavior and Fatality Rate during the 2011 Tohoku-Oki Earthquake and Tsunami, Earthquake Spectra, 31 (3), 1237-1265. 